\title{
Réquiem de um Guerreiro
}

Valmir Batista Corrêa

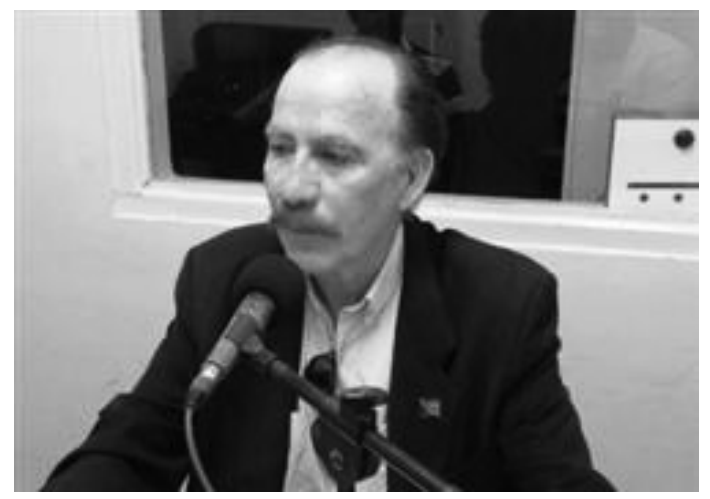

No dia 17 de março de 2014 faleceu em São Paulo, capital, Nelson Chaves dos Santos. Quem era ele? Por que a imprensa sul-mato-grossense não deu sequer uma nota sobre esse guerreiro importante na luta pela democracia contra a ditadura militar?

Nelson nasceu em Paranaíba, em 27 de abril de 1945, filho do fazendeiro João Chaves dos Santos, um dos maiores proprietários rurais locais e dono da fazenda Ariranha, no distrito denominado Raimundo. Cursou o colegial em Araçatuba e, depois, foi para a capital de São Paulo, no ano do golpe militar, engajando nas lutas estudantis contra a ditadura e também no movimento sindical. Com ele engajou-se outro seu irmão, Pedro Chaves dos Santos.

Foi um dos fundadores da Vanguarda Popular Revolucionária (VPR), organização armada de extrema esquerda que combateu o regime autoritário militar.

Perseguido pela repressão, Nelson e Pedro tiveram que fugir para Paranaíba, após serem delatados. Segundo fontes orais, os irmãos começaram a dar abrigo a dezenas de perseguidos políticos de São Paulo, Rio de Janei- 
ro e Minas Gerais, fazendo nos limites da fazenda do seu pai um arremedo de "reforma agrária", assentando gente e plantando lavoura.

Entendido pela ditadura militar como um "perigo", este foco de resistência política, após novas delações, fez com que Paranaíba sofresse uma violenta ação repressora por terra e por ar. E o mais incrível desta história é o fato dela permanecer desconhecida com o passar do tempo e, possivelmente, pelo medo provocado.

O ex-deputado Sergio Assis, então ainda menino, guarda vivos na memória aqueles acontecimentos que abalaram os moradores da pequena cidade do antigo Mato Grosso. Pelas dificuldades de comunicação, parte do exército, com seus assustadores caminhões verde-oliva e de pneus enormes, subiu o rio Santana até Aparecida do Taboado e, depois, acampou na rua Joaquim Murtinho, na saída para Cassilândia, objetivando facilitar a penetração na zona rural do Raimundo. Outra parte dos militares pulou de paraquedas de helicópteros e, segundo consta, também foram utilizados balões neste ataque.

Sem armas, os guerrilheiros/lavradores de Paranaíba e seus companheiros foram presos por centenas de militares, no dia 5 de fevereiro de 1969. Nelson relatou que muitos foram barbaramente torturados.

Mais tarde, os irmãos Nelson e Pedro, juntamente com mais sessenta e oito presos políticos, foram trocados pela libertação do embaixador suíço Giovanni Enrico Bucher, sequestrado pelo VPR sob o comando de Carlos Lamarca, no dia 7 de dezembro de 1970. A libertação do embaixador, que ficou 40 dias sob o poder dos guerrilheiros, deu-se somente três dias após a libertação dos presos políticos. O "Grupo 70", como ficaram conhecidos os presos políticos libertados, foi colocado num boeing da Varig e levado ao Chile, na ocasião governado pelo socialista Allende. O decreto $n^{\circ} 68.050$, de 13 de janeiro de 1971 baniu os "70" do território nacional como mais um ato da repressão.

Esses presos políticos foram recebidos pelo governo chileno, recebendo cidadania chilena. No Chile, Nelson foi admitido nos quadros do 
MR8, cuja organização abdicou da luta armada. Com o golpe militar e a instauração da ditadura militar chilena, sob liderança de Pinochet, Nelson conseguiu fugir para a Argentina, mas Pedro ficou preso (chegou a ser assessor de Allende) e depois obteve asilo na França.

Economista de profissão, Pedro reside hoje em Moputo, capital de Moçambique. Nelson permaneceu preso na embaixada da Argentina por 70 dias e mais tarde obteve cidadania sueca.

Mesmo banido pelo ato do governo militar, Nelson retornou ao Brasil vivendo de forma clandestina e atuando politicamente no MR8. Em março de 1979 foi novamente preso. Foi, entretanto, o primeiro preso político a ser solto, em 30 de agosto de 1979, beneficiado pela 2a . Auditoria Militar com base da Lei da Anistia, saindo do presídio Barro Branco. Com a criação dos partidos políticos, ajudou a fundar o Partido Pátria Livre (PPL), sendo seu secretário de relações internacionais.

A sua morte recente vai desfalcando uma geração de jovens idealistas que deram suas vidas, com imensos sacrifícios, por um Brasil genuinamente democrático e socialista. 